\title{
THE EXAMINATION OF PERCEIVED ORGANIZATIONAL SUPPORT (POS), ORGANIZATIONAL CYNICISM AND COUNTER PRODUCTIVE WORK BEHAVIOR (CWB) IN PUBLIC EMPLOYEES: INTERGROUP GAP ANALYSIS
}

\section{Tolga BAL ${ }^{1}$}

Dr, Sosyal Güvenlik Kurumu, Ankara E-posta: baltolga@gmail.com

ORCID: 0000-0003-1489-5338

Başvuru Tarihi:20.09.2019

Kabul Tarihi: 03.05.2021

DOI: $10.21441 /$ sosyalguvence. 948483

\begin{abstract}
Public organizations in Turkey adopted working principles such as citizen-orientation, transparency, accountability, efficiency and effectiveness with Law No. 5018 Public Financial Management and Control Law in parallel with the new development trends of giving up the traditional understanding of public administration. The most important factor is human capital in public organizations aiming at ensuring citizen satisfaction.

In this article; levels of organizational cynicism, perceived organizational support, of public employees and their counter-productive work behaviors (CWB) were analyzed according to demographic variables (age, marital status, working time, education level, service period, service class). According to results of the analysis, significant differences were found for each variable in one or more scales.

The results of this research indicates that should take measures to increase POS and reduce organizational cynicism in order to reduce and/or eliminate the CWB. So, Civil Servants Law No 657 (DMK), to which civil servants are subject, should be reformed by increasing effectiveness of merit system which is already an element of Law no 657. In this context, it should be remembered that not only competence and expertise, but also ethics and moral are an element of merit. When considering in the macro sense, merit constitutes one of the basic building blocks for the development and growth of a country in terms of both public and private sector functioning.
\end{abstract}

Keywords: Perceived organizational support (pos), organizational cynicism, counter productive work behaviors (cwb), structural equation mode (sem), civil servants

\footnotetext{
${ }^{1}$ Bu çalışma Ankara Üniversitesi Sosyal Bilimler Enstitüsü'nde kabul edilen doktora çalışmasından türetilmiştir.
} 


\section{KAMU ÇALIŞANLARINDA ALGILANAN ÖRGÜTSEL DESTEĞİN, ÖRGÜTSEL SINIZMIIN VE ÜRETKENLIK KARŞITI ISS DAVRANIŞLARININ İNCELENMESİ: GRUPLARARASI FARK ANALIZİ}

\section{$\ddot{\mathbf{O Z Z}}$}

Türkiye'de kamu örgütleri dünyadaki gelişime paralel olarak geleneksel kamu yönetimi anlayışından vazgeçerek 5018 sayılı Kamu Mali Yönetim ve Kontrol Kanunu ile vatandaş odaklılık, şeffaflık, hesap verebilirlik, verimlilik ve etkinlik çalışma ilkelerini benimsemişlerdir. Vatandaş memnuniyetini sağlamayı amaçlayan kamu kurum ve kuruluşlarında en önemli unsur ise beşeri sermayedir.

$\mathrm{Bu}$ makalede; kamu çalışanlarının örgütsel sinizm, algılanan örgütsel destek düzeylerinin ve gösterdikleri üretkenlik karşıtı iş davranışların (ÜKID) demografik değişkenlere (yaş, medeni durum, çalışma süresi, öğrenim durumu, hizmet sınıfi) göre nasıl farklılaştığı araştırılmıştır. Araştırma sonucunda, her bir değişken için bir veya daha çok ölçekte anlamlı farklılıklar bulunmuştur.

Bu araştırmanın sonuçları kamu örgütlerinin; ÜKİD'i azaltmak ve/veya ortadan kaldırmak için örgütsel desteği arttıracak ve örgütsel sinizmi azaltacak önlemler almaları gerektiğini göstermektedir. Bu bağlamda devlet memurlarının tabi olduğu 657 sayılı Devlet Memurları Kanunu (DMK)'nun zaten bir unsuru olan liyakat sisteminin etkinliğinin arttırılarak reformize edilmesi gerekmektedir. Bu kapsamda sadece yeterlilik ve uzmanlık değil ahlak ve etiğin de liyakatin bir unsuru olduğu unutulmamalıdır. Makro anlamda da düşünüldüğünde liyakat hem kamu hem özel sektör işleyişi bağlamında bir ülkenin kalkınması ve büyümesi için de temel yapı taşlarından birini oluşturmaktadır.

Anahtar Kelimeler: Algılanan örgütsel destek, örgütsel sinizm, üretkenlik karşıtı iş davranışları, yapısal eşitlik modeli, kamu çalışanları 


\section{INTRODUCTION}

Nowadays, the productivity of the employees in the organizations operating in the public service sector has been questioned and this situation has started to come up as an important and priority issue. Human capital in public organizations aiming to ensure citizen satisfaction is the most important factor in terms of increasing productivity in organizations. Employee productivity will enable organizations to achieve their goals and objectives and increase the effectiveness \& efficiency of the organization.

Work efficiency is also determined by employee productivity. The perceived organizational support (POS) and organizational cynicism levels of the employees affect the counterproductive work behaviors that may arise in this direction. This means a decrease in productivity. Thus, after the relationship between employees' organizational cynicism attitudes and CWB was determined, it will be possible to increase productivity by taking measures to prevent organizational cynicism.

The aim of this study is to examine how differs POS, organizational cynicism and CPWB by demographic variables. The article consists of three sections: conceptual framework, research methodology and analysis results. Finally, the results were discussed and suggestions were made accordingly.

\section{CONCEPTUAL FRAMEWORK}

\subsection{Organizational Cynicism}

The concept of cynicism is a broad concept and has been the subject of different disciplines of social sciences such as philosophy, religion, political science, sociology, psychology and business administration. Although this study is firstly based on "organizational cynicism", it is thought that the historical development of cynicism concept and the definitions made should be briefly mentioned.

The concept of cynicism defined as "Antisthenes' doctrine, cynicism, which argues that human beings can access themselves by virtue and happiness, free from all necessities without being bound to any value" in the Dictionary of Turkish Language Association, (TDK, 2019) and "An inclination to believe that people are motivated purely by self-interest; skepticism; An inclination to question whether something will happen or whether it is worthwhile; pessimism. ; A school of ancient Greek philosophers, the Cynics" in Oxford English Dictionary (OED, 2019), has emerged in ancient Greece as a way of life and a school of thought and has come to our day with different meanings (Brandes, 1997: 7; Dean et al. , 1998: 342).

Today, we can define cynics as "mordacious fault finders" in the simplest terms (Ersoy- 
Kart, 2015: 83). On the other hand, the existence of many kinds and definitions of cynicism leads to complexity and makes the concept difficult to understand. All of these definitions are true in their own time and discipline or at least not wrong just because important thing is in which field and for what purpose the concept of cynicism is used. For example, if cynicism is defined as a tendency to think that people have hidden goals, to care for others to protect or increase their own interests and to manage things (Tokgöz and Y1lmaz, 2008: 285), we see that this definition represents the Machiavellian view advocated by O'Hair and Cody (1987) (Brandes, 1997; Dean et al., 1998). This conceptualization of cynicism is not wrong, nor does it involve pure truth.

In this study, the definition of organizational cynicism that detailed in the next subsection is based on "negative attitude of an individual towards his/her organization" (Dean, et al., 1998: 5) made by Dean, Brandes, Dharwadkar (1998), which causes the employee to experience negative cognitive, affective and behavioral (conative) experiences towards his organization, work and ultimately hisself/herself.

In other words, organizational cynicism includes "an attitude that includes the belief that the organization lacks integrity" and "negative feelings and humiliating or critical behaviors towards the organization" (Dean, et al., 1998).

\subsubsection{Components of organizational cynicism}

In the literature, the presence of components are accepted in important and strong attitudes as "cognitive, emotional and conative (behavioral)" without hierarchical order among them ones (Göksu, 2007: 89-105; Güney, 2009: 120-127; Kağıtçıbaş1, 2013: 110-170). In the context of organizational cynicism literature, the authors who focused on this subject until 1996 focused on the cognitive component (Brandes, 1997: 29-30). But after Dean et al. (1997) study covering all three dimensions in 1997, all three components were accepted by many authors (Abraham, 2000; Bernerth, et al., 2007; Brandes \& Das, 2006; Ersoy-Kart, M., 2015; James, 2005; Kağıtçıbaşı, 2013; Kalağan \& Güzeller, 2010; Kalağan, 2009; Neves, 2012). This study is based on these three components as accepted in the literature.

\section{Cognitive Component}

The cognitive component, which states "the belief that organizational cynicism is devoid of honesty (Kalağan, 2009: 46), shows the thoughts and beliefs of employees with cynical attitude when examined within the framework of organizational cynicism.

Employees who think and have these beliefs such as practices are devoid of organizational principles, official statements (notifications) are not taken seriously by 
employees, people are deceitful, selfish insincere, lazy, inconsistent and untrustworthy, employees lie, fraudulent, unscrupulous and immoral behavior and so on. In their organization have the cognitive element of organizational cynicism (Brandes, 1997: 30; Brandes and Das, 2006: 237; Dean et al., 1998: 345-346; Kalağan, 2009: 46).

\section{Affective Component}

The cognitive component that includes emotions which are defined as positive or negative by the individual, arising from cynical beliefs and thoughts; It expresses strong emotional reactions such as disrespect, pain, anger, distress and embarrassment (Brandes and Das, 2006: 237; Dean et al, 1998: 346; Abraham, 2000: 269).

These feelings can spring in cynical employees related to any negative emotions in such cases; A sense of disdain and anger towards their organization, pain, disgust, even shame when they think of their organizations, when they are assigned to a task they do not want or to worry when they are given a job beyond their capacity (Brandes, 1997: 31; Dean et al., 1998: 346).

The concept of contemporary affective component has been expanded by adding an affect of smugness. According to this view, as well as the emotions expressed above, cynical individuals have attitudes such as nurture disdain, frustration and insecurity towards other people or objects and believe that they are superior, more knowledgeable and/or correct than other people (Brandes and Das, 2006: 237; James, 2005: 6).

\section{Conative Component}

Finally, the conative (behavioral) component expresses the inclination and probability of cynic attitude to behavior. In this context, cynical employees can behave negatively, often humiliating people by using humor, which is their most effective weapon, and making cynical comments about the business environment, the aims of their organizations and their job descriptions (Brandes, 1997: 34-35; Dean et al., 1998: 346).

In addition, behaviors of cynical employees can be an example of the conative component such as constantly complaining about their organization, criticizing everything, meaningful gaze, grinning and smiling in a condescending way (Brandes and Das, 2006: 240).

Cynical workers do not stand behind its organization when it is talked negatively or unfairly about its organization; on the contrary, it tends to denigrate the organization itself (Dean et al., 1998: 346).

\subsection{Perceived Organizational Support (POS)}

Organizational support theory based on "Social Exchange Theory (Blau, 1964) and "The Norm of Reciprocity" (Gouldner, 1960) expresses that employee's contribution to the 
organization and the effort made to the job, in other words, the organization has the necessary features to make the employees happy and feel comfortable (Eisenberger et al, 1986; Eisenberger et al., 2001, Neves, 2012).

Perceived organizational support (POS), which is one of the main elements of the analysis conducted in this study expresses that all the behaviors and attitudes developed by the employee towards the organization due to the value of the employee for organization depending on above-mentioned contributions and efforts. (Eisenberger et al, 1986: 500-501). In other words, POS ( or perception of organizational support) is that employees are aware of the organization's contribution to them, feel themselves safe and feel the presence of the organization stands behind them (Eisenberger et al., 1986: 500-501). POS is influenced by positive or negative policies, norms, procedures and activities that affect the employees of the organization (Eisenberger et al., 2001: 42).

POS increases with the fact that the organization assigns human characteristics to the employees, in other words, does not see them as soulless machine parts, and cares about the personality traits, qualities and capacities of the employees. (Eisenberger et al., 1986: 501).

Thus, employees with high levels of organizational support can internalize decisions and activities carried out within the organization at a higher level. (Rhoades \& Eisenberger, 2002: 699). According to Rhodes and Eisenberger (2002), in order to develop organizational support perception, there must be four important precursors: "organizational justice, administrative support, organizational rewards and work conditions and employee characteristics. "

According to the theory of POS (Eisenberger et al., 1986), employees have general beliefs about the organization and these beliefs include the organization's commitment to the contributions and well-being of employees. (Eisenberger et al., 1986: 503). This definition of Eisenberger et al. is based on the following assumptions (Eisenberger et al., 1986: 503):

- Assuming the employee contributes to the organization,

- The employee's perception that the employee's contribution is considered valuable by the organization and that the organization strives to ensure the employee's well-being in return.

Kraimer and Wayne are classified POS as "adjustment POS, career POS, and financial POS" (Kraimer \& Wayne, 2004: 217-218):

- The adjustment POS is defined as the organization's involvement in the adaptation of the employee (including his family) in the process following the business transfers. 
- The career POS is that the organization is concerned with the employee's career need.

- The financial POS is that the organization deals with the financial needs of employees and rewards employees' contributions in terms of compensating and working benefits.

A high level of perceived organizational support may mean that employees perceive the organization as good and positive, if this level is low, they perceive as bad and negative (Eisenberger et al., 1986: 503). In the context of organizational cynicism, this situation may reveal increasing the level of organizational cynicism as decreasing the POS of employees.

For example, employees can create cynical attitudes when they are to do a job effectively and to overcome stressful situations if they have the perception that they cannot get help from the organization and that the organization will not stand behind them. So, the perceived weak organizational support level may lead to a negative emotional bond between the organization and the employees (Byrne \& Hochwarter, 2008: 55).

\subsection{Counterproductive work behaviors (CWB)}

Counterproductive work behaviors (CWB) can be simply defined as behaviors that harm the organization and its members (Martinko et al., 2002: 37). Such behaviors may consist of direct-active actions such as sabotage, aggression, theft, physical-verbal assault, as well as indirect-passive actions such as non-compliance, deliberate misconduct, withdrawal, being late, quitting, etc. (Fox et al., 2001: 292, Spector \& Fox, 2005: 152).

CWB were initially called as "deviant behaviors" that is defined as "behaviors that reveal unacceptable violations by breaching important norms and threatening the society" (Robinson \& Bennett, 1995: 556-557). In this context, deviant behaviors, in other words, behaviors that go beyond normal measures; behaviors that have the potential to cause harm to the organization and / or its members (Robinson and Bennett, 1995: 556-557). 
Figure 1: Scope of Counterproductive work behaviors (CWB)

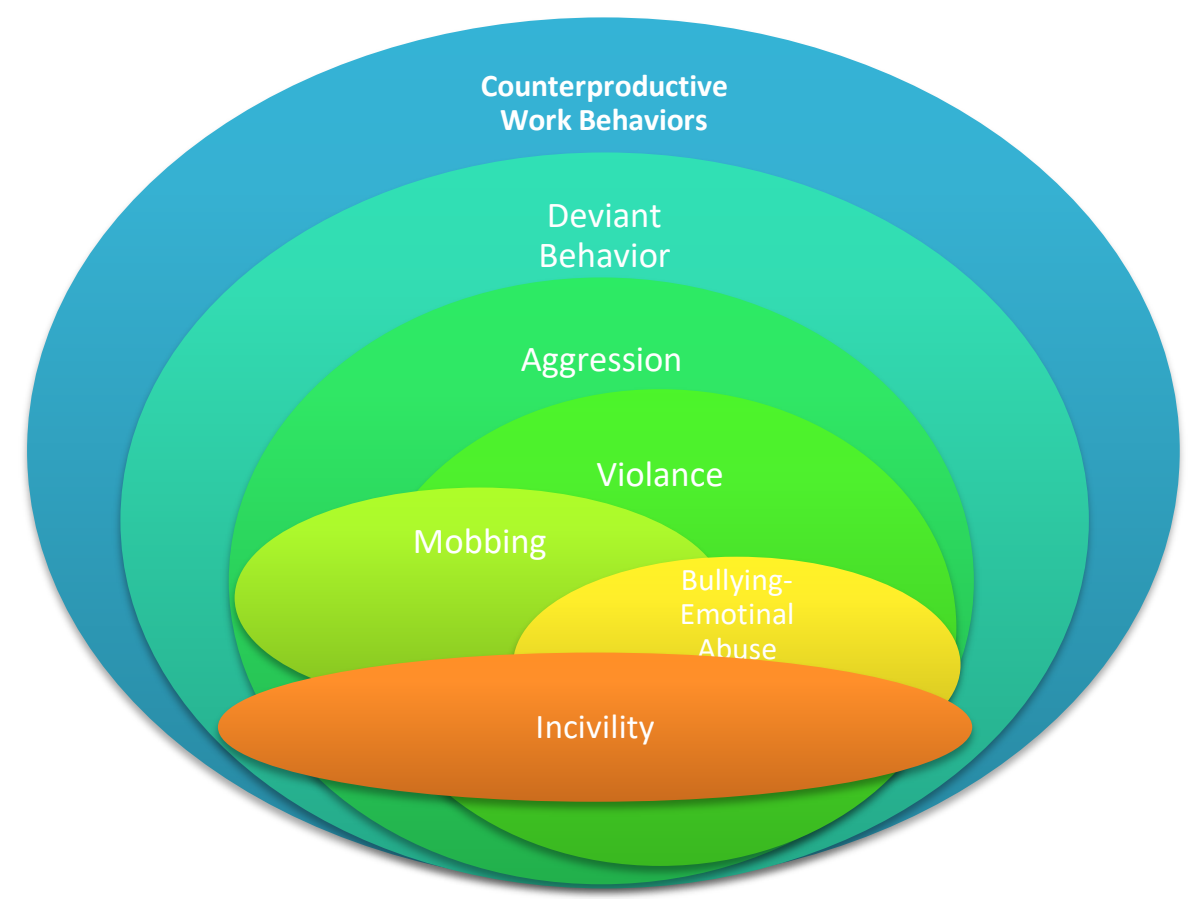

Source: Pearson et al., 2005: 191

As stated in Figure 1, the scope of the CWB has expanded from the initial conceptualization to the present day and has become a phenomenon that encompasses many concepts. In this context, it is stated that CWB represents these types of behaviors, which include incivility, bullying, emotional abuse, mobbing, (physical) violence, aggression, and deviant bahivors which consist of harmful behaviors towards both the organization and its members (Pearson et al., 2005: 190-191).

Then, concept was further expanded by Spector et al. (2011) and described CWB in five components. According to Spector et al. (2011) classification, which is also based on this study, the CWB consists of five dimensions: abuse against others, production deviance, sabotage, withdrawal and theft (Spector et al., 2006: 448; Spector, 2011: 343).

\subsubsection{Components of counterproductive work behaviors (CWB)}

This subsection contains detailed core-explanations of the five components of the CWB. While the behavior of abuse against others is mostly considered as the behavior of individual CWB (behavior towards the individual), the production deviance, sabotage, withdrawal and theft behaviors are mostly considered as behaviors of organizational CWB.

1. Abuse against others

Abuse against others (abuse) is defined as an individual behavior that harm colleagues and / or stakeholders within the organization (Spector et al., 2006: 448). These behaviors can 
consist of physical harm such as humiliation, disdain, disregard, ugly criticism, humiliating comments, intimidation, etc., also can be made up of psychological actions such as ignoring and preventing (secretly) effective working (Spector et al., 2006: 448). However, since direct physical violence is rarely encountered in organizations, many researchers focus on behaviors that do not involve physical harm (Spector et al., 2006: 448).

The concept of abuse here is closely related to such concepts as; incivility, emotional abuse, workplace bullying and psychological mobbing that are in the relevant literature. However, the focus of such studies is on those who target such behavior as incivility, emotional abuse, workplace bullying and psychological mobbing. In the context of CWB studies, the focus is on those who do these behaviors (Spector et al., 2006: 448).

\section{Production deviance}

The component of production deviance includes behaviors such as not deliberately and properly performing the tasks in the job description of the employee, making mistakes, performing poorly, slowing down and obeying the instructions (Spector et al., 2006: 449).

Spector et al. (2006) approached the concept of production deviance parallel to Hollinger's (1986) view, which classified behaviors such as deliberate absenteeism, perpetually arriving late under production deviance, however Spector et al. deliberately categorized those behaviors under the withdrawal component. (Spector et al., 2006: 449).

Production deviance is considered as more passive and safer type of behavior than sabotage by some researchers because it is a behavior towards organizational goals (non-living beings), not an individual (living beings) (Spector et al., 2006: 449).

\section{Sabotage}

Sabotage behavior is that employees consciously sabotage or destroy (arson, damage property) organizational assets (equipment) to reduce productivity and / or harm the organization (Spector et al., 2006: 449). In fact, the sabotage behavior can be considered the expanded version or derivation form of the machine-breaking actions that occurred as a result of the workers' movements after the industrial revolution.

In some studies, sabotage behavior is taken from a wider perspective and defined that is done for the purpose of harming the organizational functioning, disrupting or deflecting the organizational order for the personal interests of the employees, making negative rumors about the organization, embarrassing the organization, slowing production, damaging organizational property, disrupting business relations or damaging customers and employees such as negative behaviors (Ambrose et al., 2002: 948; Skarlicki et al., 2008: 1335). 
The sabotage behavior can come into view depending on a number of factors that cause anger or hostile feelings such as the aim of providing individual benefit, drawing attention to any problem, resisting organizational change, gaining the consent of colleagues or gaining superiority over the colleagues (Ambrose et al., 2002: 948; Spector et al., 2006: 449).

\section{Withdrawal}

Withdrawal consists of such as behaviors that deliberately reducing the time limiting the working time of employees: not going to work, coming to work late, leaving early, frequent leave without cause, long-term non-work phone calls, longer breaks than allowed time (coffee, tea, etc.) and non-work appointments (Spector, 2000: 237-238; Spector et al., 2006: 450). In this context, absenteeism of employees as intentional and conscious without any reason, affects organizational motivation and productivity negatively (Spector et al., 2006: 450).

Unlike other CBW components, employees exhibit in this component avoidance (behavior) rather than direct negative behavior to avoid stressors, injustice, dissatisfaction or situations that create negative emotions (Spector, 2000: 237-238; Spector et al., 2006: 450).

Withdrawal is caused by job dissatisfaction (in particular), health problems, psychological disorders, stress, social norms, culture, subordinate-parent conflict, work-family conflict and individual differences (Spector, 2000: 237-238; Spector et al., 2006 450).

Since withdrawal behavior is an attempt to avoid a situation rather than direct harm instead of direct damage, it differs from other counterproductive work behaviors. The individual who exhibits the withdrawal behavior, perhaps does not want to directly harm the organization, in fact, stressors, injustice, dissatisfaction or want to move away from situations that create negative emotions (Spector, 2000: 237-238; Spector et al., 2006: 450).

\section{Theft}

The theft, as the last dimension means theft of employees with the idea of harming the organization or individuals. (Spector and Fox, 2002: 271; Spector et al., 2006: 449). Theft behaviors towards the organization may arise due to economic needs, perception of job dissatisfaction, injustice (Mustaine and Tewksbury, 2002: 113-114) and is not seen as aggressive behavior by many employees (Neuman and Baron, 1997: 45).

Although it is thought that theft behavior is mostly exhibited because of economic interests, theft behavior is considered as an attacking tool against the organization (Spector et al., 2006: 449). In this context, employees do not intend to use or sell the goods they thieved, but rather aim to harm the organization economically. 


\section{METHOD OF RESEARCH}

In this study, data were collected by using a questionnaire based on quantitative research method based on scales whose validity and reliability were tested. In this sense, the type of this applied research, which is designed on the basis of field research, can be expressed as relational research.

\subsection{Research Model}

Figure 2 shows the model of this research.

Figure 2: Research Model

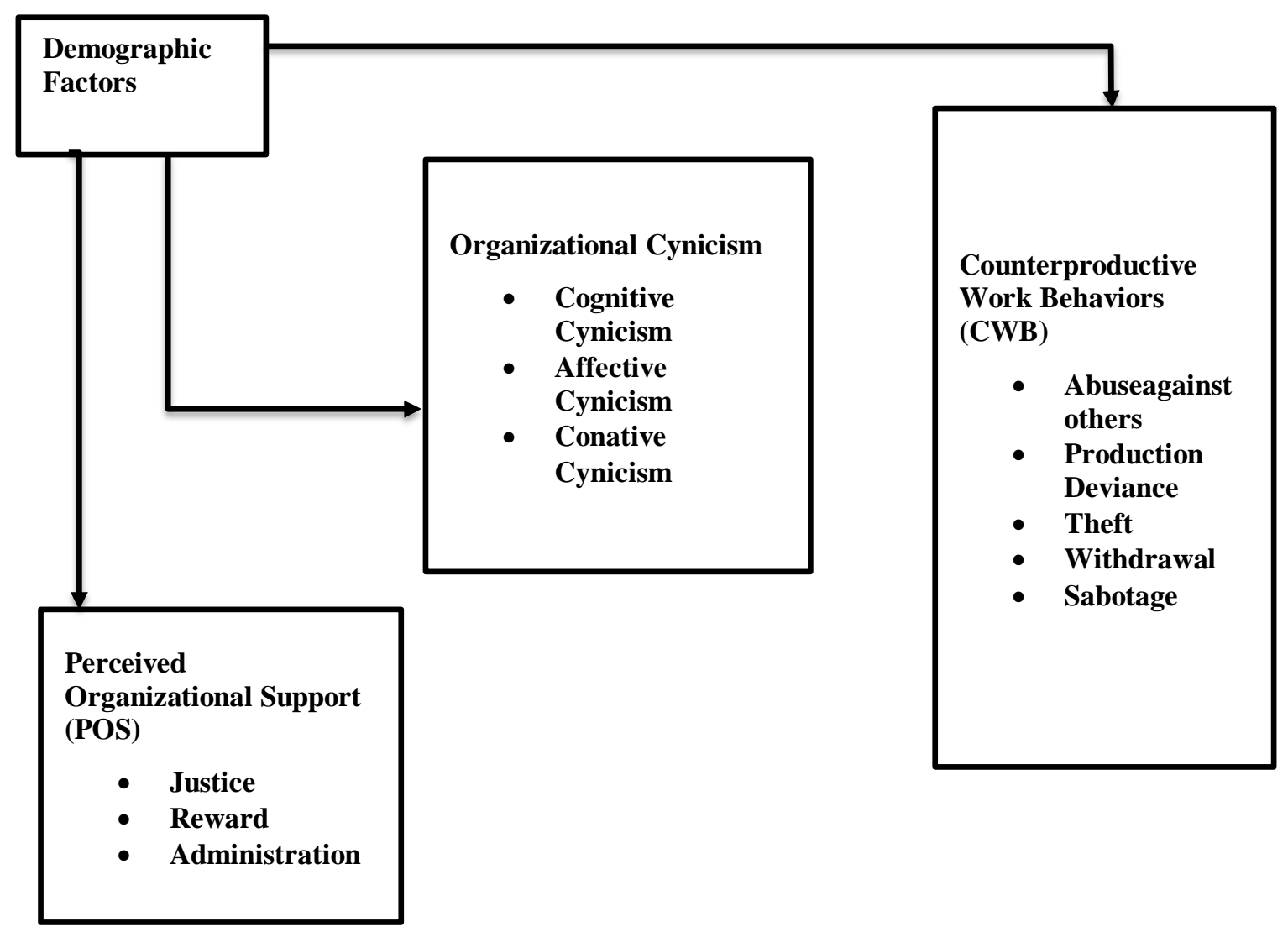

As it is seen in Figure 2, which tries to make the conceptual structure of the research problem more understandable with a simple visual, those are examined that the relations betweendemographic data and scales of POS, organizational cynicism and CWB.

In this context, this model analyze how scales differs according to demographic variables and demonstrated results in this regard. The variance analysis results applied to the scores obtained from the scales (POS, Organizational Cynicism and CPWB) are given. In all variance analyzes, demographic variables (gender, age, marital status, educational level, service period and service class) were taken as an independent variable and POS; organizational 
cynicism and CPWB scales and their sub-scales were taken as dependent variables. In this context, significant differences within each group were revealed and the others were ignored.

\subsection{Purpose of Research}

This study aims to examine; how differs POS, organizational cynicism and CPWB by demographic variables.

\subsection{Limitations of The Research}

Social willingness" and "ego defense" tendencies can emerge in the self-transfer (selfassessment) method used in the measurement of perceived organizational support, organizational cynicism and CWB. In other words, participants can express themselves with the mood they want to be by hiding their true feelings about the subject. Conducting the research process assuming that the answers given by the participants are correct constitutes the most important limitation of this research.

Due to time constraints and cost reasons this research is limited by the scales applied to 419 public officials, which are included in a very wide range spectrum and only three of the service classes (general administration services, technical services and education services) among public employees consisting of 12 service classes. It should be noted that all service classes and even different occupational groups in these classes are shaped by different variables such as work environments, different service rights.

\subsection{Sampling Strategy}

Systematic sampling method was preferred in order to represent a certain cadre (general administration services, technical services and education and training services) and random sampling method was used for the determination of the persons in these cadres (Yazicioglu and Erdogan, 2004: 40-50). The sample of the study consists of 419 public employees selected by simple random sampling method.

384 people are sufficient after 1 million when; the diameter of the sample selected from the population of more than 1 million people has not changed, accepted that 0.05 sampling errors, the probability of sampling selection and non-selection is taken as equal and 0.05 . Therefore, 419 public employees who express our sample in this research provide this condition. This sample group was reached through social media, face-to-face interviews and direct e-mails.

\subsection{Data Collection Tools}

In this study, data were collected in 2016-2017 by using some scales which were tested for validity and reliability in the manuscript based on quantitative research method in order to reach the aforementioned objectives. The scales in the appendix were applied as follows and 
the data were collected:

- In the first section, through the demographic information of the participants (age, gender, marital status, working time, education level, service class),

- In the second part, through the "Perceived Organizational Support Scale" (Nayır, 2014), based on the scale developed by Eisenberger et al. (1986) with 28 items (questions 1 to 28 on the scale; Cronbach Alpha $(\alpha)=0,94)$,

- In the third section, through the "Organizational Cynicism Scale" (Kalağan, 2009), based on the scale developed by the Dean et al. (1998) with 13 items (questions 29 to 41 of the scale; Cronbach Alpha $(\alpha)=0,93)$.

- In the fourth section; through the "Counterproductive Work Behavior (CWB) Scale" (Kılıç, 2013) based on the scale developed by Spector et al., (2011) with 40 items (4281 questions in the scale; Cronbach Alpha $(\alpha)=0,94)$.

The preceived organizational support consist of components of "justice, reward, administration". Organizational cynicism consists of components of "cognitive cynicism, affective cynicism, conative cynicism". CWB consist of components of "abuse, production Deviance, theft, withdrawal, sabotage.

\section{ANALYSIS RESULTS}

\subsection{Demographic Data For Participants}

As shown in Table 1, data were collected from a total of 419 people, 190 female and 229 male participants. $45 \%$ of the participants are women and 55\% are men. Approximately $58 \%$ of the participants are in the 30-34 age range, which is the most intensive age group. The next intensive group is the 22-29 age group, which can be called youth.

Approximately $81 \%$ of the participants got a bachelor degree with 338 people, while $19 \%$ of the participants got a master's degree with 81 people. When the service period is examined, the dominant group is having service life of 6-10 years with $65 \%$. This is a natural result of the fact that $80 \%$ of the participants are between $30-40$ years old.

When the distribution of participants according to service class is examined; it is seen that approximately $68 \%$ of them work in general administrative services class, $16.5 \%$ work in education services class and $15 \%$ work in technical services class. 
Table 1: Demographic Data for Participants

\begin{tabular}{|c|c|c|c|}
\hline Data Classification & & Number of People & Percent (\%) \\
\hline \multicolumn{4}{|l|}{ Gender } \\
\hline & Woman & 190 & 45,3 \\
\hline & Man & 229 & 54,7 \\
\hline & Total & 419 & 100,0 \\
\hline \multicolumn{4}{|l|}{ Age } \\
\hline & $22-29$ & 47 & 11,2 \\
\hline & $30-34$ & 244 & 58,2 \\
\hline & $35-39$ & 96 & 22,9 \\
\hline & $40-44$ & 27 & 6,4 \\
\hline & $45-65$ & 5 & 1,2 \\
\hline & Total & 419 & 100,0 \\
\hline \multicolumn{4}{|l|}{ Marital Status } \\
\hline & Single & 141 & 33,7 \\
\hline & Married & 278 & 66,3 \\
\hline & Total & 419 & 100,0 \\
\hline \multicolumn{4}{|l|}{ Educational level } \\
\hline & Bachelor Degree & 338 & 80,7 \\
\hline & Master's Degree & 81 & 19,3 \\
\hline & Total & 419 & 100,0 \\
\hline \multicolumn{4}{|l|}{ Service Period } \\
\hline & $1-5$ years & 48 & 11,5 \\
\hline & $6-10$ years & 275 & 65,6 \\
\hline & 11-15 years & 67 & 16,0 \\
\hline & $16-20$ years & 15 & 3,6 \\
\hline & 21 years and more & 14 & 3,3 \\
\hline & Total & 419 & 100,0 \\
\hline \multicolumn{4}{|l|}{ Service Class } \\
\hline & $\begin{array}{l}\text { Education and } \\
\text { Training Services }\end{array}$ & 69 & 16,5 \\
\hline & $\begin{array}{l}\text { General } \\
\text { Administration } \\
\text { Services }\end{array}$ & 287 & 68,5 \\
\hline & Technical services & 63 & 15,0 \\
\hline & Total & 419 & 100,0 \\
\hline
\end{tabular}

\subsection{Findings on Intergroup Gap Analysis}

In this section, the results of the variance analysis applied to the scores obtained from the scales are given. In all variance analyzes, demographic variables (gender, age, marital status, education level, service period and class) were independent variables and perceived organizational support (POS), organizational cynicism and counterproductive work behaviors (CWB) scales and their sub-scales were taken as dependent variables. In this context, significant 
(meaningful) differences within each group were revealed and the others were ignored.

To compare different pairs of means and see which are significantly different from each other the Tukey-Kramer test is used by SPSS which is using the group sizes are unequal. The power advantege of this test depends on the assumption that all possible pairwise comparisons are being made.

i) Results of Intergroup Gap Analysis in Terms of Perceived Organizational Support (POS) and Its Subscales

There is no significant difference between the groups according to gender.

When evaluating results according to age groups, significant differences were found between groups in scale of justice $(\mathrm{F}=4.49 ; \mathrm{p}<0.05)$, reward $(\mathrm{F}=4.47 ; \mathrm{p}<0.05)$ and (total) perceived organizational support $(\mathrm{F}=2.80 ; \mathrm{p}<0.05)$ that are shown in Table 2 . In the justice subscale, averages of age groups, 22-29 (Group 1), 30-34 (Group 2), 35-39 (Group 3), 40-44 (Group 4), 45-65 (Group 5), are respectively: 31.13; 30.64; 32.88; 38.56 and 28.40. According to the results of Tukey-Kramer Test to determine the source of the difference; significant differences were found between Group 1 - Group $4(q=7.4 ; p<0.05)$ and Group 3 - Group 4 $(q=7.9 p<0.05)$. For the scores obtained from the award subscale, the averages of age groups are respectively: $12.83 ; 12.65 ; 12.28 ; 15.56$ and 8.00 . According to the results of Tukey-Kramer Test to determine the source of the difference between the groups, significant differences were found between Group 2 - Group $4(\mathrm{q}=2.9 ; \mathrm{p}<0.05)$, Group 3 - Group $4(\mathrm{q}=3.3 ; \mathrm{p}<0.05)$ and Group 5 - Group 4 ( $q=7.6 ; \mathrm{p}<0.05)$. When looking to the perceived organizational support; the averages of the $1 \mathrm{st}, 2 \mathrm{nd}, 3 \mathrm{rd}$, 4th, 5 th groups are respectively: 63.04; 62.87; 65.06; 73.33 and 52. According to the results of Tukey-Kramer Test to determine the source of the difference; a significant difference was found between Group 2 and Group 4 ( $q=10.5 ; p<0.05)$. As can be seen in public organizations, in the age group of 40-44 perceive higher organizational support compared to public officials; in the age groups of 22-29 and 30-34 age groups in the context of justice and in the age groups of 22-29, 30-34 and 45-65 in the context of awards. When the perceived organizational support score averages are considered, public employees in the 40-44 age group have a higher perception of organizational support than public employees do in the 30-34 age group in parallel with the above-mentioned results. 
Table 2: Table of Intergroup Gap Analysis Results for Perceived Organizational Support and Its Subscales by Age

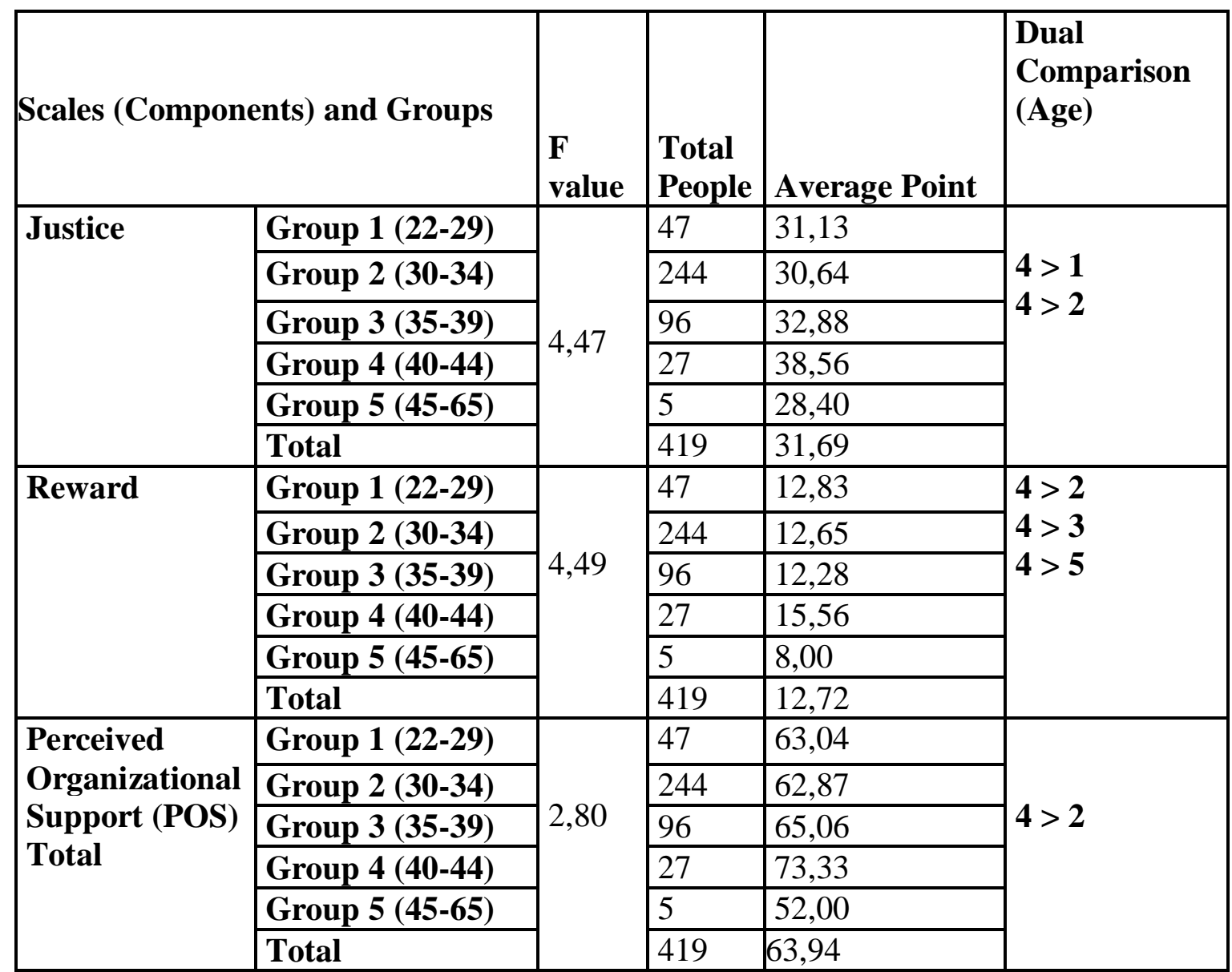

When evaluating results according to marital status, significant difference was found between single and married people in the justice $(F=5.83 ; p<0.05)$ subscale. In the justice subscale, averages respectively are 30.04 and 32.53 for single and married people. As can be seen, the perception of organizational support of single people is lower than married people do.

When evaluating results according to education level, significant differences were found between people who have Bachelor Degree and Master's Degree, in all subscales (Justice: F = 10.22; $\mathrm{p}<0.05$; Administration: $\mathrm{F}=5.06 ; \mathrm{p}<0.05$; Reward: $\mathrm{F}=9.96 ; \mathrm{p}<0.05$ ) and totally POS $(\mathrm{F}=5.83 ; \mathrm{p}<0.05)$ scale. Averages for people who have Bachelor Degree and Master's Degree respectively are; 32,47 and 28,62 in the justice subscale, 19,85 and 18,28 in the administration subscale, 13,05 and 11,40 in the reward subscale. The mean scores of totally POS respectively are 65.37 and 58.31. As can be seen, people who have master degree perceive lower organizational support than people who have Bachelor Degree.

When evaluating results according to service period, significant differences were found between groups in subscale of justice $(F=4.44 ; p<0.05)$, administration $(F=2.76$; $p<0.05)$ 
and perceived organizational support (total) $(\mathrm{F}=2.68 ; \mathrm{p}<0.05)$ scale. Tukey-Kramer test was used to determine the source of the difference. When the results are evaluated; significant differences were found between Group 1 - Group 5 ( $q=9.6$; $\mathrm{p}<0.05)$, Group 2 - Group 5 ( $\mathrm{q}=$ 7.7; $\mathrm{p}<0.05)$ and Group 3 - Group $5(\mathrm{q}=10.6 ; \mathrm{p}<0.05$. In the administration subscale, the averages of the 1st, 2nd, 3rd, 4th and 5th groups respectively are 19.27; 20.09; 17.90; 19,67 and 17.

Table 3: Table of Intergroup Gap Analysis Results for Perceived Organizational Support and Its Subscales by Service Period

\begin{tabular}{|c|c|c|c|c|c|}
\hline \multicolumn{2}{|c|}{ Scales and Groups } & $\begin{array}{l}\text { F } \\
\text { value }\end{array}$ & $\begin{array}{l}\text { Total } \\
\text { People }\end{array}$ & Average Point & \begin{tabular}{|l|} 
Dual \\
Comparison \\
(Service \\
Period)
\end{tabular} \\
\hline \multirow[t]{6}{*}{ Justice } & Group 1 (1-5) & \multirow{6}{*}{4,44} & 48 & 30,06 & \multirow{6}{*}{$\begin{array}{l}5>1 \\
5>2 \\
5>3\end{array}$} \\
\hline & Group $2(6-10)$ & & 275 & 31,99 & \\
\hline & Group 3 (11-15) & & 67 & 29,09 & \\
\hline & Group 4 (16-20) & & 15 & 35,67 & \\
\hline & Group 5 (21-25) & & 14 & 39,64 & \\
\hline & Total & & 419 & 31,69 & \\
\hline \multirow[t]{6}{*}{ Reward } & Group $1(1-5)$ & \multirow{6}{*}{2,76} & 48 & 19,27 & \multirow{6}{*}{$2>3$} \\
\hline & Group 2 (6-10) & & 275 & 20,09 & \\
\hline & Group 3 (11-15) & & 67 & 17,90 & \\
\hline & Group 4 (16-20) & & 15 & 19,67 & \\
\hline & Group 5 (21-25) & & 14 & 17,00 & \\
\hline & Total & & 419 & 19,53 & \\
\hline \multirow{6}{*}{$\begin{array}{l}\text { Perceived } \\
\text { Organizational } \\
\text { Support (POS) } \\
\text { Total }\end{array}$} & Group 1 (1-5) & \multirow{6}{*}{2,68} & 48 & 62,17 & \multirow{6}{*}{$2>3$} \\
\hline & Group 2 (6-10) & & 275 & 64,89 & \\
\hline & Group 3 (11-15) & & 67 & 58,66 & \\
\hline & Group 4 (16-20) & & 15 & 68,87 & \\
\hline & Group 5 (21-25) & & 14 & 71,21 & \\
\hline & Total & & 419 & 63,94 & \\
\hline
\end{tabular}

According to the results of Tukey-Kramer Test to determine the source of the difference; a significant difference was found between Group 2 and Group $3(q=2.2 ; p<0.05)$. In the perceived organizational support (total) scale, averages of the 1st, 2nd, 3rd, 4th and 5th groups respectively are 62,$17 ; 64.89 ; 58.66 ; 68.87$ and 71.21 . According to the results of TukeyKramer Test to determine the source of the difference; a significant difference was found between Group 2 and Group $3(q=6.24 \mathrm{p}<0.05)$. As it can be seen, in parallel with the results obtained by age, public employees who have service period (experience) with 21-25 years, perceive higher organizational support than public employees who have service period with 1- 
5, 6-10 and 11-15 years do in the context of justice. Public employees who have 6-10 years seniority perceive higher organizational support than public employees who have 11-15 years seniority do in the context of administration. When considering the perceived organizational support (total) scale, in line with the results stated above in age comparison, public employees who have 6-10 years seniority perceive higher organizational support than public employees who have 11-15 years seniority do.

There is no significant difference between groups according to service classes.

ii) Results of Intergroup Gap Analysis in Terms of Organizational Cynicism and Its Components (Subscales)

When evaluating results according to gender, significant difference was found between men and women in cognitive cyncisim $(\mathrm{F}=6,9 ; \mathrm{p}<0,05)$. In the cognitive cynicism subscale, the averages for men and women respectively are 17.77 and 16.79. As can be seen, women experience a higher level of cognitive cynicism than men.

When evaluating results according to age groups, significant differences were found between groups in all scales (Cognitive: $F=2,64 ; \mathrm{p}<0,05$; Affective: $\mathrm{F}=3,62 ; \mathrm{p}<0,05$; Conative: $\mathrm{F}=3,24 ; \mathrm{p}<0,05$; Org. Cyn.: $\mathrm{F}=2,57$; $\mathrm{p}<0,05)$ in terms of avareges that are shown in Table 4. In the cognitive cynicism subscale, averages of age groups, 22-29 (Group 1), 30-34 (Group 2), 35-39 (Group 3), 40-44 (Group 4), 45-65 (Group 5), are respectively: 17,00; 17,50; 17,$06 ; 15,33$ and 19,80. According to the results of Tukey-Kramer Test to determine the source of the difference; significant differences were found between Group 3 - Group 4 ( $q=2,2 ; p<$ 0,05). For the scores obtained from the affective cynicism subscale, the averages of age groups are respectively: 13,$17 ; 12,80 ; 12,01 ; 14,63$ and 18,20. According to the results of TukeyKramer Test to determine the source of the difference between the groups, significant differences were found between Group 3 - Group 5 ( $q=6,2 ; p<0,05)$. In the conative cynicism subscale, averages of age groups, 22-29 (Group 1), 30-34 (Group 2), 35-39 (Group 3), 40-44 (Group 4), 45-65 (Group 5), are respectively: 14,45; 13,40; 12,43; 13,11 ve 15,60. According to the results of Tukey-Kramer Test to determine the source of the difference; significant differences were found between Group 1 - Group 3 ( $q=2 ; \mathrm{p}<0,05)$. When looking to the organizational cynicism (total); the averages of the 1st, 2nd, 3rd, 4th, 5th groups are respectively: 44,62;43,70;41,50; 43,07 and 53,60. According to the results of Tukey-Kramer Test to determine the source of the difference; a significant difference was found between Group 3 and Group 5 ( $q=12,1 ; \mathrm{p}<0,05)$. As can be seen in public organizations, people who is in the age group of 40-44 has lower cognitive cynicism compared to public officials; in the 
age groups of 30-34. Also, people who is in the age group of 35-39 has lower affective cynicism compared to public officials in the age groups of 45-65 and lower conative cynicism compared to public officials in the age groups of 22-29. When looking organizational cynicism (total), people who is in the age group of 35-39 has lower organizational cynicism compared to public officials in the age groups of 45-65 in parallel with the above-mentioned results.

When evaluating results according to marital status, significant differences was found between single and married people in conative subscale $(\mathrm{F}=15,81 ; \mathrm{p}<0,05)$ and organizational cynicism $(\mathrm{F}=5,78 ; \mathrm{p}<0,05)$ scale. For single and married people, averages respectively are 14,27 and 12,81 in the conative subscale and 44,97 ve 42,56 in organizational cynicism scale. As can be seen, single people have higher organizational cynicism than married people do. There is no significant difference between groups according to educational level.

Table 4: Table of Intergroup Gap Analysis Results for Organizational Cynicism and Its Subscales (Components) by Age

\begin{tabular}{|c|c|c|c|c|c|}
\hline \multirow{2}{*}{\multicolumn{2}{|c|}{ Scales (Components) and Groups }} & F value & $\begin{array}{l}\text { Total } \\
\text { People }\end{array}$ & Average Point & $\begin{array}{l}\text { Dual } \\
\text { Comparison } \\
\text { (Age) }\end{array}$ \\
\hline & & \multirow{6}{*}{2,64} & 47 & 17,00 & \multirow{6}{*}{$3>2$} \\
\hline \multirow{5}{*}{$\begin{array}{l}\text { Cognitive } \\
\text { Cynicism }\end{array}$} & Group 2 (30-34) & & 244 & 17,50 & \\
\hline & Group 3 (35-39) & & 96 & 17,06 & \\
\hline & Group 4 (40-44) & & 27 & 15,33 & \\
\hline & Group $5(45-65)$ & & 5 & 19,80 & \\
\hline & Total & & 419 & 17,23 & \\
\hline \multirow{6}{*}{$\begin{array}{l}\text { Affective } \\
\text { Cynicism }\end{array}$} & Group 1 (22-29) & \multirow{6}{*}{3,62} & 47 & 13,17 & \multirow{6}{*}{$3>5$} \\
\hline & Group $2(30-34)$ & & 244 & 12,80 & \\
\hline & Group $3(35-39)$ & & 96 & 12,01 & \\
\hline & Group $4(40-44)$ & & 27 & 14,63 & \\
\hline & Group 5 (45-65) & & 5 & 18,20 & \\
\hline & Total & & 419 & 12,84 & \\
\hline \multirow{6}{*}{\begin{tabular}{|l|} 
Conative \\
Cynicism
\end{tabular}} & Group 1 (22-29) & \multirow{6}{*}{3,24} & 47 & 14,45 & \multirow{6}{*}{$1>3$} \\
\hline & Group 2 (30-34) & & 244 & 13,40 & \\
\hline & Group 3 (35-39) & & 96 & 12,43 & \\
\hline & Group $4(40-44)$ & & 27 & 13,11 & \\
\hline & Group $5(45-65)$ & & 5 & 15,60 & \\
\hline & Total & & 419 & 13,30 & \\
\hline \multirow{6}{*}{$\begin{array}{l}\text { Organizational } \\
\text { Cynicism } \\
\text { (Total) }\end{array}$} & Group 1 (22-29) & \multirow{6}{*}{2,57} & 47 & 44,62 & \multirow{6}{*}{$5>3$} \\
\hline & \begin{tabular}{|l|} 
Group 2 (30-34) \\
\end{tabular} & & 244 & 43,70 & \\
\hline & \begin{tabular}{|l|} 
Group 3 (35-39) \\
\end{tabular} & & 96 & 41,50 & \\
\hline & Group $4(40-44)$ & & 27 & 43,07 & \\
\hline & Group 5 (45-65) & & 5 & 53,60 & \\
\hline & Total & & 419 & 43,37 & \\
\hline
\end{tabular}


When evaluating results according to service period, significant differences were found between groups in cognitive cynicism $(\mathrm{F}=6,65 ; \mathrm{p}<0,05)$ subscale and organizational cynicism (total) $(\mathrm{F}=2,53 ; \mathrm{p}<0,05)$ scale. In the cognitive cynicism subscale, the averages of the 1 st, 2nd, 3 rd, 4th and 5th groups respectively are 17,65; 16,88; 19,09; 16,47 and 14,71. According to the results of Tukey-Kramer Test that determining the source of the difference; a significant difference was found between Group 2 and Group $3(q=2,2 ; p<0,05)$ and Group 3 - Group 5 $(q=4,4 ; p<0,05)$. In the organizational cynicism scale, the averages of the 1st, 2nd, 3rd, 4th and 5th groups respectively are 46,02; 42,58; 45,58; 41,40 and 41,43. According to the results of Tukey-Kramer Test that determining the source of the difference; a significant difference was found between Group 2 and Group 3 ( $q=3 ; \mathrm{p}<0,05)$. So public employees who have 11 15 years seniority; have higher cognitive cynicism than public employees do with 6-10- \& 2125-years seniority and have higher organizational cynicism than public employees do with 610 years seniority do in the context of organizational cynicism.

Table 5: Table of Intergroup Gap Analysis Results for Organizational Cynicism and Its Subscales (Components) by Service Period

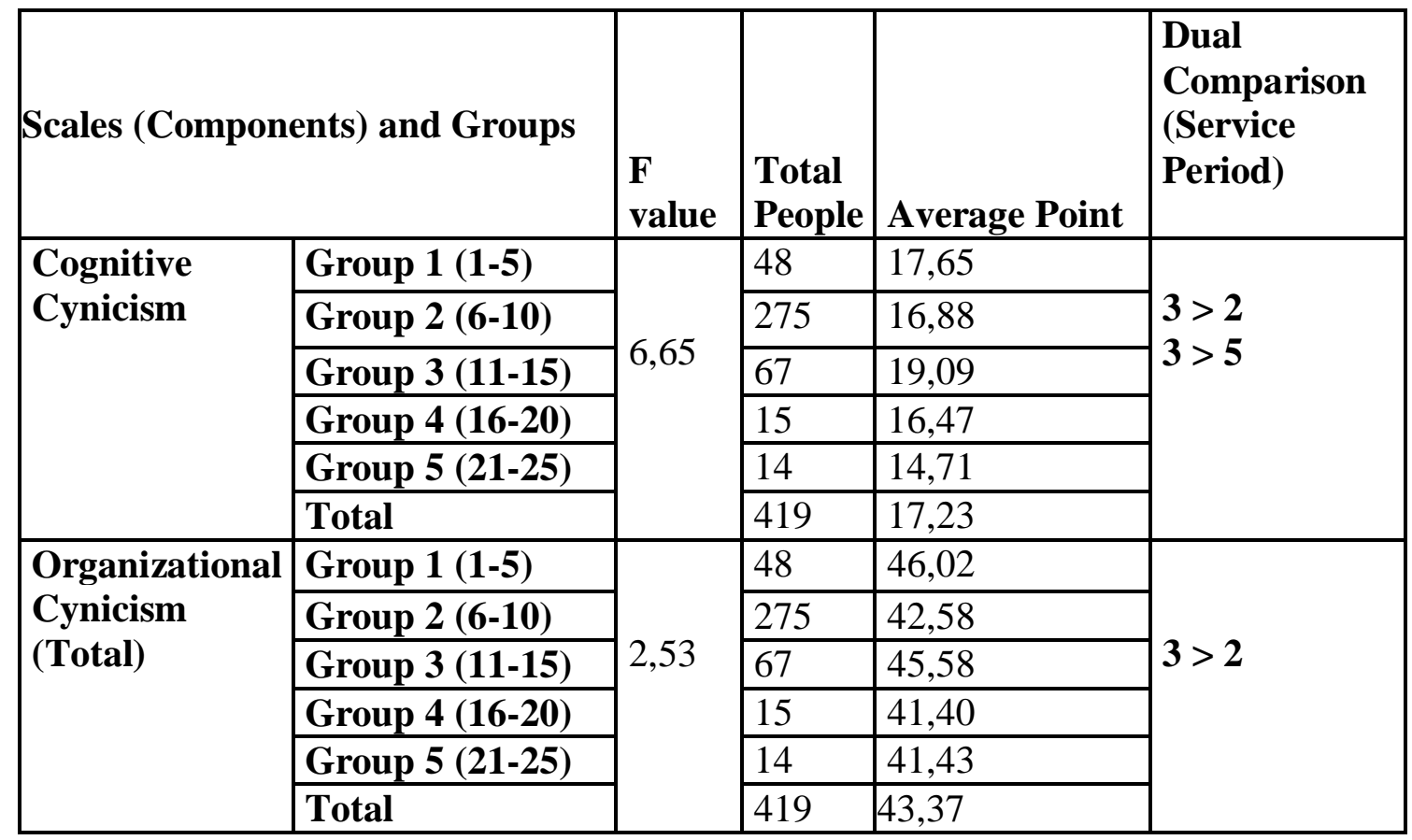

There is no significant difference were found between groups according to service classes. 


\section{iii) Results of Intergroup Gap Analysis in Terms of Counterproductive Work Behaviros (CWB) and Its Components (Subscales)}

When evaluating results according to gender, significant differences were found between men and women in all subscales (Sabotage: $F=20,73$; $p<0,05$; Withdrawal: $F=20,64$; $\mathrm{p}<0,05$; Production Deviance: F=27,49; $\mathrm{p}<0,05$; Theft: $\mathrm{F}=13,66$; $\mathrm{p}<0,05$; Abuse Against Others: $\mathrm{F}=34,05 ; \mathrm{p}<0,05)$ and counterproductive work behaviors (CWB) scale $(\mathrm{F}=41,42 ; \mathrm{p}<$ 0,05). The averages for men and women respectively are: in the sabotage subscale 3,22 and 3,67 ; in the withdrawal subscale 11,92 and 13,91 ; in the production deviance subscale 6,59 and 7,78; in the theft subscale 5,06 and 5,48; in the abuse against others subscale 19,99 ve 22,62; in the CWB scale 46,78 and 53,47. As can be seen, men show CWB more often than women.

When evaluating results according to age groups, significant differences were found between groups in scales of withdrawal, abuse against others, CWB (Withdrawal: F=20,64; $p$ $<0,05$, Abuse Against Others: $F=34,05 ; \mathrm{p}<0,05 ; \mathrm{CWB}: \mathrm{F}=41,42 ; \mathrm{p}<0,05)$ in terms of avareges that are shown in Table 6. In the withdrawal subscale, averages of age groups, 22-29 (Group 1), 30-34 (Group 2), 35-39 (Group 3), 40-44 (Group 4), 45-65 (Group 5), are respectively: 11,$62 ; 13,64 ; 13,30 ; 9,48$ and 8,40 . According to the results of Tukey-Kramer Test to determine the source of the difference; significant differences were found between Group 2 - Group 4 $(\mathrm{q}=4,16 ; \mathrm{p}<0,05)$ and Group 3 - Group $4(\mathrm{q}=3,82 ; \mathrm{p}<0,05)$. For the scores obtained from the abuse against others subscale, the averages of age groups are respectively: 20,34;22,06; 20,$79 ; 19,70$ and 22,80. According to the results of Tukey-Kramer Test to determine the source of the difference; although there is a significant difference across groups, this difference does not appear in groups. This difference may occur if the number of samples increases. When looking to the CWB (total) scale; the averages of the 1st, 2nd, 3rd, 4th, 5th groups are respectively: 47,96;51,69;50,67;43,48 and 46,00. According to the results of Tukey-Kramer Test to determine the source of the difference; a significant difference was found between Group 2 - Group 4 ( $q=8,2 ; p<0,05)$ and Group 3 - Group $4(q=7,2 ; p<0,05)$. As can be seen in public organizations, people who is in the age group of 40-44 exhibit less CWB compared to public officials; in the age groups of 30-34 and 35-39. 
Table 6: Table of Intergroup Gap Analysis in Terms of Counterproductive Work Behaviros (CWB) and Its Components (Subscales) by Age

\begin{tabular}{|c|c|c|c|c|c|}
\hline \multicolumn{2}{|c|}{ Scales (Components) and Groups } & $\begin{array}{l}\text { F } \\
\text { value }\end{array}$ & $\begin{array}{l}\text { Total } \\
\text { People }\end{array}$ & $\begin{array}{l}\text { Average } \\
\text { Point }\end{array}$ & $\begin{array}{l}\text { Dual } \\
\text { Comparison } \\
\text { (Age) }\end{array}$ \\
\hline \multirow[t]{7}{*}{ Withdrawal } & Grup 1 (22-29) & \multirow{7}{*}{4,49} & 47 & 11,62 & \multirow{7}{*}{$\begin{array}{l}2>4 \\
3>4\end{array}$} \\
\hline & Grup 2 (30-34) & & 244 & 13,64 & \\
\hline & Grup 3 (35-39) & & 96 & 13,30 & \\
\hline & Grup 4 (40-44) & & 27 & 9,48 & \\
\hline & Grup 5 (45-65) & & 5 & 8,40 & \\
\hline & Toplam & & 419 & 13,01 & \\
\hline & \begin{tabular}{|l|} 
Toplam \\
\end{tabular} & & 419 & 21,43 & \\
\hline \multirow{6}{*}{$\begin{array}{l}\text { Counterproductive } \\
\text { Work Behaviors } \\
\text { (CWB) }\end{array}$} & Grup 1 (22-29) & \multirow{6}{*}{2,80} & 47 & 47,96 & \multirow{6}{*}{$\begin{array}{l}2>4 \\
3>4\end{array}$} \\
\hline & \begin{tabular}{|l} 
Grup 2 (30-34) \\
\end{tabular} & & 244 & 51,69 & \\
\hline & \begin{tabular}{|l|} 
Grup 3 (35-39) \\
\end{tabular} & & 96 & 50,67 & \\
\hline & Grup 4 (40-44) & & 27 & 43,48 & \\
\hline & Grup 5 (45-65) & & 5 & 46,00 & \\
\hline & Toplam & & 419 & 50,44 & \\
\hline
\end{tabular}

When evaluating results according to marital status, significant differences were found between single and married people in all subscales (Sabotage: $F=31,14 ; \mathrm{p}<0,05$; Withdrawal: F=30,9; $p<0,05$; Production Deviance: F=13,29; $<$ < 0,05; Theft: $F=15,66 ; p<0,05$; Abuse Against Others: $\mathrm{F}=19,44 ; \mathrm{p}<0,05)$ and counterproductive work behaviors (CWB) scale $(\mathrm{F}=35,99 ; \mathrm{p}<0,05)$. The averages for single and married respectively are: in the sabotage subscale 3,84 and 3,27; in the withdrawal subscale 14,70 and 12,15 ; in the production deviance subscale 7,83 and 6,95; in the theft subscale 5,61 and 5,13; in the abuse against others subscale 22,84 and 20,72; in the CWB scale 54,82 and 48,22. As can be seen, single people exhibit CWB more often than married people do.

When evaluating results according to education level, significant difference was found between people who have Bachelor Degree and Master's Degree, in withdrawal subscale $(\mathrm{F}=4,58 ; \mathrm{p}<0,05)$. Averages for people who have Bachelor Degree and Master's Degree respectively are; 12,77 and 13,95. So people who have master degree show CWB more otften than people who have Bachelor Degree do.

When evaluating results according to service period, significant differences were found between groups in all subscales except abuse against others (Sabotage: $F=3,2 ; p<0,05$; Withdrawal: $\mathrm{F}=6,39 ; \mathrm{p}<0,05$; Production Deviance: $\mathrm{F}=3,86 ; \mathrm{p}<0,05$; Theft: : $\mathrm{F}=5,52 ; \mathrm{p}<$ 
$0,05)$ and counterproductive work behaviors $(\mathrm{CWB})$ scale $(\mathrm{F}=6,27 ; \mathrm{p}<0,05)$ those shown on Table 7. In the sabotage subscale, the averages of the 1st, 2nd, 3rd, 4th and 5th groups respectively are 3,$85 ; 3,47 ; 3,27 ; 3,00 ; 3,43$. According to the results of Tukey-Kramer Test that determining the source of the difference; a significant difference was found between Group 1 - Group $3(q=0,59 ; \mathrm{p}<0,05)$ and Group 1 - Group $4(q=0,85 \mathrm{p}<0,05)$. In the withdrawal subscale, the averages of the 1st, 2nd, 3rd, 4th and 5th groups respectively are 15,00;13,21; 12,$00 ; 10,40$ and 9,86. According to the results of Tukey-Kramer Test that determining the source of the difference; a significant difference was found between Group 1 - Group 3 ( $q=3$; $\mathrm{p}<0,05)$, Group 1 - Group 4 ( $\mathrm{q}=4,6 ; \mathrm{p}<0,05)$ and Group 1 - Group 5 ( $\mathrm{q}=5,14 ; \mathrm{p}<0,05)$. In the production deviance subscale, the averages of the 1st, 2nd, 3rd, 4th and 5th groups respectively are 8,$23 ; 7,27 ; 6,85 ; 6,13 ; 6,43$.

According to the results of Tukey-Kramer Test that determining the source of the difference; a significant difference was found between Group 1 - Group 3 ( $q=1,38 ; p<0,05$ ) and Group 1 - Group 4 ( $q=2,1 ; \mathrm{p}<0,05)$. In the theft subscale, the averages of the 1 st, $2 \mathrm{nd}$, 3 rd, 4 th and 5th groups respectively are 6,$02 ; 5,22 ; 5,18 ; 5 ; 5$. According to the results of TukeyKramer Test that determining the source of the difference; a significant difference was found between Group 1 - Group 2 ( $q=0,8 ; p<0,05)$, Group 1 - Group 3 (q=0,8; p <0,05), Group 1 - Group 4 ( $\mathrm{q}=1 ; \mathrm{p}<0,05)$ and Group 1 - Group $5(\mathrm{q}=1 ; \mathrm{p}<0,05)$. In the CWB scale, the averages of the 1st, 2nd, 3rd, 4th and 5th groups respectively are 56,08; 50,63; 48,22; 44,20 and 44,57. According to the results of Tukey-Kramer Test that determining the source of the difference; a significant difference was found between Group 1 - Group 2 ( $q=5,45 ; \mathrm{p}<0,05)$, Group 1 - Group 3 (q=7,86; p < 0,05), Group 1 - Group 4 ( $q=11,89 ; \mathrm{p}<0,05)$ and Group 1 Group $5(\mathrm{q}=11,51 ; \mathrm{p}<0,05)$. So public employees who have 1-5 years seniority, in other words, young employees show more often CWB than compared to employees in other age groups.

When evaluating results according to service classes, significant differences were found between groups in scales of withdrawal and CWB (Withdrawal: $F=4,49 ; p<0,05$; CWB: $\mathrm{F}=2,80 ; \mathrm{p}<0,05)$ in terms of avareges. In the withdrawal subscale, the averages by class of education and training services, general administration services and technical services respectively are 10,$42 ; 13,49$ and 13,62. According to the results of Tukey-Kramer Test that determining the source of the difference; a significant difference was found between education and training services and general administration services $(q=3,07 ; \mathrm{p}<0,05)$, education and training services and technical services $(q=3,2 ; \mathrm{p}<0,05)$. In the CWB scale, the averages by 
class of education and training services, general administration services and technical services respectively are 45,99; 51,16 and 52,02. According to the results of Tukey-Kramer Test that determining the source of the difference; a significant difference was found between education and training services and general administration services ( $q=5,18 ; \mathrm{p}<0,05)$, education and training services and technical services $(q=6,03 ; \mathrm{p}<0,05)$. So public employees in educationservice class exhibit less often CWB than public employees working in class of general administration and technical services. 
Table 7: Table of Intergroup Gap Analysis in Terms of Counterproductive Work Behaviors

(CWB) and Its Components (Subscales) by Service Period

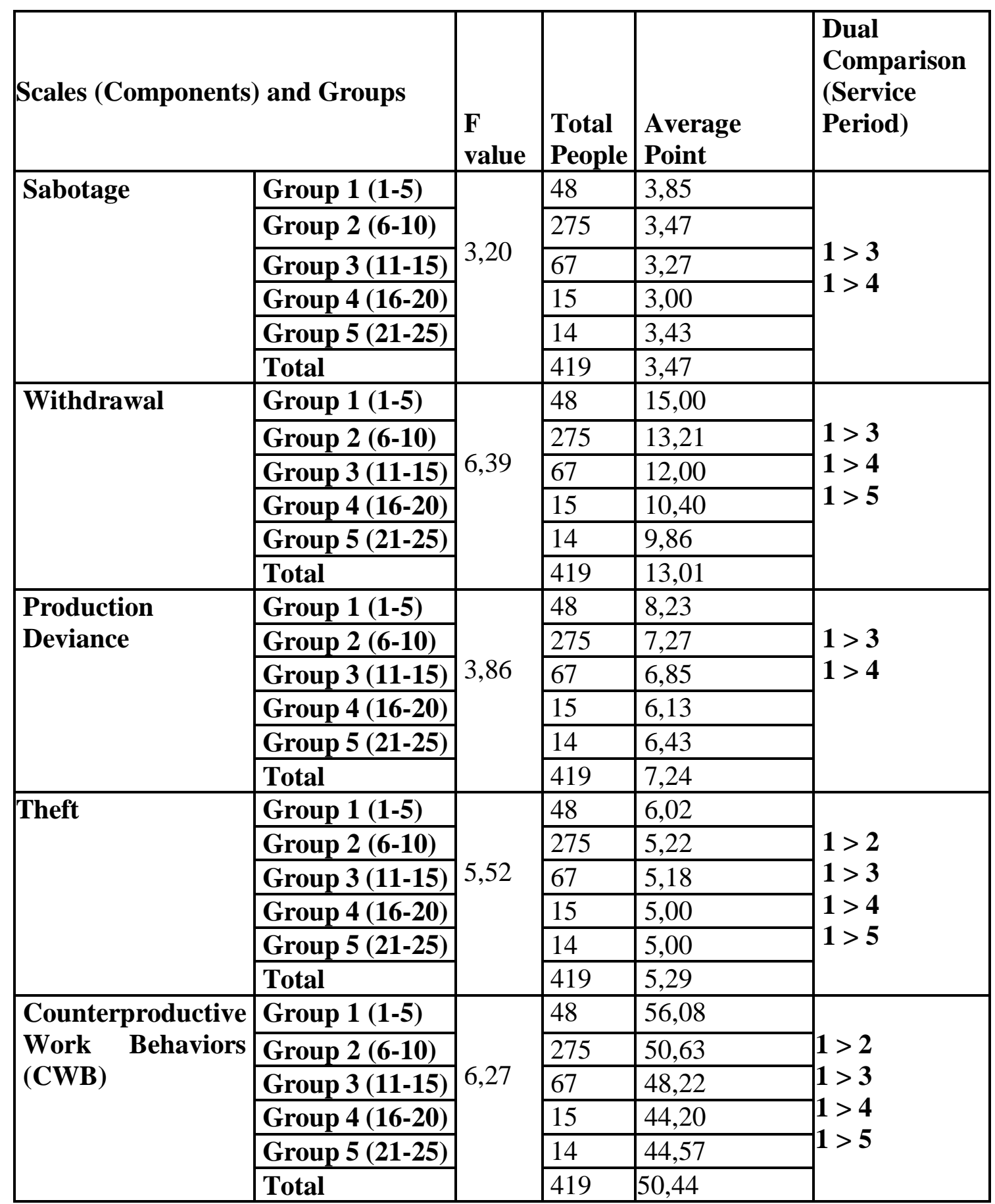

\section{RESULTS, DISCUSSION AND CONCLUSION}

In this study; the gap(differences) between the groups were analyzed according to demographic variables (age, gender, marital status, service period, education level, service class) in the context of perceived organizational support (POS), organizational cynicism and counterproductive work behaviors (CWB) of public employees. 
When evaluating gap according to gender of public employees; although women feel higher cognitive cynicism than men do, men exhibit more counter-productive work behavior (CWB) than women.in the context of all subscales of CWB (theft, withdrawal, production deviance, sabotage, abuse against others). This result is parallel to some studies (Mirvis and Kanter, 1991; Chiaburu, et al., 2013) conducted to date and can be explained by the relative reluctance of men to reveal their behaviors because of their sexist roles. On the other hand, there also are many studies, which found that no significant relationship between gender and organizational cynicism (Andersson and Bateman, 1997; Bernerth et al., 2007; Bommer et al., 2005; Efilti et al., 2008; Erdost et al., 2007; Fero, 2005; Güzeller and Kalağan, 2009 James, 2005; Tokgöz and Y1lmaz, 2008) or indicating that women's employees have higher levels of organizational cynicism than male workers (Lobnika, 2004). As we have seen, more studies are needed for a healthy causal relation.

When evaluating gap according to age group of public employees, it was observed that public employees in the "age group 40-44" perceive higher levels of organizational support, have lower levels of cognitive and a conative cynicism, and exhibit lower (frequency) CWB as expected. These results are similar to previous studies (Chiaburu, et al., 2013; Mirvis and Kanter, 1991; Johnson, 2007). On the other hand, although public employees in the "age group 45-65" differ from other groups due to their lower perceptions of organizational support and higher levels of organizational cynicism, do not exhibit a relatively higher CWB. This result is similar to some studies that could not detect a meaningful relationship between organizational support, cynicism and CWB (Andersson and Bateman, 1997; Fero, 2005; Bernerth et al., 2007; Bommer et al., 2005; Efilti, et al., 2008; Erdost, et al., 2007; Güzeller and Kalağan, 2009; James, 2005; Tokgöz and Y1lmaz, 2008). As we have seen, more work is needed for a healthy causal relation.

When evaluating gap according to marital status of public employees, it is seen that singles has lower organizational support and have higher cynicism than married people do. As a result, they exhibit more CWB, particularly withdrawal and abuse against others. This situation can be explained by the fact that singles have more expectations from the workplace and working conditions than married people do. As married poeple receive higher support from their family and take less risk by considering their families in working life and/or they decrease their expectations because of seeing working life in the background. Although this result is similar to studies of Delken's in 2004 and Kanter \& Mirvis in 1989, in these studies, it has been found that the level of organizational cynicism is higher in separate or divorced employees than 
in married or single employees. On the other hand, there are studies (Efilti et al., 2008; Erdost et al., 2007) that do not have a meaningful relationship between marital status and organizational cynicism.

When evaluating gap according to level of educational level of public employees, it is seen that people who have bachelor degree perceive higher organizational support and exhibit lower withdrawal behavior than others. In other words, as the level of education increases, perceived organizational support decreases and CWB increases. There was no significant difference in organizational cynicism. This result is similar to the studies (Andersson and Bateman, 1997; Bommer et al., 2005; Efilti et al., 2008; James, 2005) in which founded no significant relationship between organizational cynicism and education level. On the other hand, there are studies (Chiaburu, et al., 2013; Fero, 2005; Güzeller and Kalağan, 2009; Tokgöz and Y1lmaz, 2008) that have obtained significant results between these two variables. These results can be explained by the lack of a satisfactory award and the inadequacy of merit according to Civil Servants Law No 657 (DMK) to which civil servants are subject. So, Civil Servants Law No 657 (DMK) should be reformed in orter to eliminate these negativeness, by increasing effectiveness of justice, merit which is already an element of Law no 657. In this context, it should be remembered that not only competence and expertise, but also ethics and moral are an element of merit. When considered in the macro sense, merit constitutes one of the basic building blocks for the development and growth of a country in terms of both public and private sector functioning.

When evaluating gap according to service period of public employees; similar results found as expected comparing age of public employees who has "1-5 years and 6-10 years" experience with having lower levels of organizational support and higher levels of organizational cynicism and exhibiting more CWB. These results are similar to those of previous studies (Brandes, 1997; James, 2005; Lobnika, 2004). That is to say, relatively young employees attach higher importance to organizational justice and reward, are more cynical and as a result exhibit more CWB. In this context, for this group, which is expected to remain in the public working life for a long time, improvement efforts should be carried out such as reforming the public award and justice system. Otherwise, these employees will be cynical and exhibit more CWB. On the other hand, there are also studies (Bernerth et al., 2007; Bommer et al., 2005, Efilti et al., 2008; Erdost et al., 2007; Tokgöz and Y1lmaz, 2008) that do not have a meaningful relationship between service period and organizational cynicism

When evaluating gap according to service classes of public employees; there is no 
difference in the context of organizational support and cynicism, it is seen that those who work in the education and training class (teachers) show less CWB than those who work in the general administration and technical services classes. This result can be explained by the fact that other groups work in the office environment and do not work directly service providers as teachers (students) and and the teachers' work practice prevents their level of particularly withdrawal and total CWB.

Finally, the next studies may focus on specific sectoral classifications such as publicprivate, industry-service-agriculture, and these mentioned sectors can be examined individually on a particular subject. In addition, it will be healthier to work with sufficient sample by targeting only one occupational group or Institution, as each of those is shaped by different variables within itself. When enough research results emerge, these results will be the basis for the meta-analysis. 


\section{REFERENCES}

Abraham, R., (2000). Organizational Cynicism: Bases and Consequences. Genetic, Social, and General Psychology Monographs. 126(3). Ağustos. 269-292.

Ambrose, M. L., Seabright, M. A., \& Schminke, M. (2002). Sabotage in the Workplace: The Role of Organizational Injustice. Organizational Behavior and Human Decision Processes. 89(1). 947-965.

Andersson, L. M., Bateman, T.S., (1997). Cynicism in the Workplace: Some Causes and Effects. Journal of Organizational Behavior. 18(5). 449-469.

Avşaroğlu, S., Deniz, M. E., \& Kahraman, A. (2005). Teknik Öğretmenlerde Yaşam Doyumu İş Doyumu ve Mesleki Tükenmişlik Düzeylerinin İncelenmesi. Selçuk Üniversitesi Sosyal Bilimler Enstitüsü Dergisi. (14). 115-129.

Bernerth, J. B., Armenakis, A. A., Feild, H. S., \& Walker, H. J. (2007). Justice, Cynicism, and Commitment: a Study of Important Organizational Change Variables. The Journal of Applied Behavioral Science. 43(3). 303-326.

Bommer, W.H., Rich, G.A., Rubin, R.S. (2005). Changing Attitudes about Change: Longitudinal Effects of Transformational Leader Behavior on Employee Cynicism about Organizational Change. Journal of Organizational Behavior. 26. 733-753.

Brandes, P., \& Das, D. (2006). Locating Behavioral Cynicism at Work: Construct Issues and Performance Implications. inside Employee Health, Coping and Methodologies. Emerald Group Publishing Limited. 233-266.

Brandes, P.M. (1997). Organizational Cynicism: Its Nature, Antecedents, and Consequences. Yayınlanmamış Doktora Tezi. Cincinnati: The University of Cincinnati.

Büyüköztürk, Ş. (2012). Sosyal Bilimler için Çok Değişkenli İstatistik: SPSS ve LISREL Uygulamaları. Ankara: Pegem Akademi Yayıncılık.

Byrne, Z.S., Hochwarter, W.A., (2008). Perceived Organizational Support and Performance Relationships across Levels of Organizational Cynicism. Journal of Managerial Psychology. Say1: 23(1). 54-72.

Chiaburu, D. S., Peng, A. C., Oh, I. S., Banks, G. C., \& Lomeli, L. C. (2013). Antecedents and Consequences of Employee Organizational Cynicism: A Meta-Analysis. Journal of Vocational Behavior. 83(2). 181-197.

Çekmecelioğlu, H. G. (2005). Örgüt Ikliminin Iş Tatmini Ve Işten Ayrılma Niyeti Üzerindeki Etkisi: Bir Araştırma. CÜ İktisadi ve İdari Bilimler Dergisi. 6(2). 23-39.

Dean Jr, J.W., Brandes, P., Dharwadkar, R., (1998). Organizational Cynicism. The Academy of Management Review. 23(2). 341-352.

Delken, M.. (2004). Organizational Cynicism: A Study among Call Centers. Yayınlanmamış Yüksek Lisans Tezi. University of Maastricht. 
Efilti, S., Gönen, Y., \& Öztürk, F. (2008). Örgütsel Sinizm: Akdeniz Üniversitesi'nde Görev Yapan Yönetici Sekreterler Üzerinde Bir Alan Araştirmas1. 7. Ulusal Büro Yönetimi ve Sekreterlik Kongresi. Trabzon: Karadeniz Teknik Üniversitesi. 1-14.

Eisenberger, R., Armeli, S., Rexwinkel, B., Lynch, P. D., Rhoades, L. (2001). Reciprocation of Perceived Organizational Support. Journal of Applied Psychology. 86(1). 42-51.

Eisenberger, R., Huntington, R., Hutchison, S., Sowa, D. (1986). Perceived Organizational Support. Journal of Applied Psychology. 71(3). 500-507.

Erdost, H. E., Karacaoğlu, K., Reyhanoğlu, M., (2012). Örgütsel Sinizm Kavramı Ve Ilgili Ölçeklerin Türkiye'deki Bir Firmada Test Edilmesi. 15. Ulusal Yönetim ve Organizasyon Kongresi Bildiri Kitabı. 514-524.

Ersoy-Kart, M. (2015). Örgütsel Sinizm, Bağlamsal Performans ve Etik Ídeoloji. Nobel Yayınc1lik. Ankara.

Fox, S., Spector, P. E., Miles, D. (2001). Counterproductive Work Behavior (Cpwb) In Response to Job Stressors and Organizational Justice: Some Mediator and Moderator Tests for Autonomy and Emotions. Journal of Vocational Behavior. 59. 291-309.

Göksu, T., (2007). Sosyal Psikoloji. Ankara: Seçkin Yayıncılık.

Güney, S., (2009). Sosyal Psikoloji. Ankara: Nobel Yayıncılık.

Güzeller C. \& Kalağan G., (2008). Örgütsel Sinizm Ölçeğinin Türkçeye Uyarlanmasi Ve Çeşitli Değişkenler Açisindan Eğitim Örgütlerinde Incelenmesi. 16. Ulusal Yönetim ve Organizasyon Kongresi Bildiri Kitabı. 87-94.

James, M. S. L., (2005). Antecedents And Consequences Of Cynicism In Organizations: An Examination Of The Potential Positive And Negative Effects On School System. Unpublished Doctoral Dissertation. The Florida State University.

Kağıtçıbaşı Ç., (2013). Günümüzde İnsan ve İnsanlar Sosyal Psikolojiye Giriş. İstanbul: Seçkin Yayincilik.

Kalağan, G. \& Güzeller C.O., (2010). Öğretmenlerin Örgütsel Sinizm Düzeylerinin Incelenmesi. Pamukkale Üniversitesi Ë̆itim Fakültesi Dergisi. 27. 83-97.

Kalağan, G., (2009). Araştırma Görevlilerinin Örgütsel Destek Algıları Ile Örgütsel Sinizm Tutumları Arasındaki Ilişki. Yayınlanmamış Yüksek Lisans Tezi. Antalya: Akdeniz Üniversitesi Sosyal Bilimler Enstitüsü.

Kılıç, S., (2013). Algılanan Örgütsel Etik İklim Ile Üretkenlik Karşıtı İş Davranışları Arasındaki Ilişkiler. Yayınlanmış Doktora Tezi. Niğde: Niğde Üniversitesi Sosyal Bilimler Enstitüsü.

Kraimer, M.L., and Wayne, S.J. (2004). An Examination Of Perceived Organizational Support As A Multidimensional Construct In The Context Of An Expatriate Assignment. Journal of 
Management. 30. 209-237.

Lobnika, B. (2004). The Prevalence And Nature Of Police Cynicism In Slovenia (From Policing In Central And Eastern Europe: Dilemmas Of Contemporary Criminal Justice). (Edt. Gorazd Mesko, Milan Pagon, and Bojan Dobovsek). the Faculty of Criminal Justice. Slovenia: University of Maribor. 103-111.

Mustaine, E. E., \& Tewksbury, R. (2002). Workplace theft: An analysis of student-employee offenders and job attributes. American Journal of Criminal Justice. 27(1). 111-127.

Nayır, F., (2013). Algılanan Örgütsel Destek Ölçeğinin Kısa Form Geçerlik Güvenirlik Çalışması. Mehmet Akif Ersoy Üniversitesi Ë̆itim Fakültesi Dergisi. 28. 89-106.

Neuman, J. H., \& Baron, R. A. (1997). Aggression in the Workplace. Antisocial Behavior in Organizations. 37-67.

Neves, P., (2012). Organizational Cynicism: Spillover Effects on Supervisorsubordinate Relationships and Performance. The Leadership Quarterly. 23. 965-976.

OED. 2019. https://en.oxforddictionaries.com/definition/cynicism (Erişim: 24.08.2019)

Pearson, C. M., Andersson, L. M. ve Porath, C. L. (2005). Workplace Incivility içerisinde S. Fox ve P. E. Spector (Ed). Counterproductive Work Behavior: Investigations of Actors And Targets. 177-200.

Rhoades, L., \& Eisenberger, R. (2002). Perceived Organizational Support: A Review Of The Literature. Journal of Applied Psychology. 87(4). 698-714.

Robinson, S. L., \& Bennett, R. J. (1995). A Typology of Deviant Workplace Behaviors: A Multidimensional Scaling Study. Academy of Management Journal. 38(2). 555-572.

Skarlicki, D. P., Van Jaarsveld, D. D., \& Walker, D. D. (2008). Getting Even For Customer Mistreatment: The Role of Moral Identity in the Relationship between Customer Interpersonal Injustice and Employee Sabotage. Journal of Applied Psychology. 93(6). 1335.

Spector, P. E. (2000). Industrial and Organizational Psychology: Research and Practice (2.b.). New York: John Wiley \& Sons Inc.

Spector, P. E. (2011). The Relationship of Personality to Counterproductive Work Behavior (Cwb): An Integration of Perspectives. Human Resource Management Review. 21(4). 342-352.

Spector, P.E. \& Fox, S., (2002). An Emotion-Centered Model of Voluntary Work Behavior: Some Parallels between Counterproductive Work Behavior and Organizational Citizenship Behavior. Human Resource Management Review. 12(2). 269-92.

Spector, P.E., Fox, S.; Penney, L.M.; Brursema, K; Goh, A., Kessler, S. (2006). The Dimensionality of Counterproductivity: Are All Counterproductive Behaviors Created Equal? Journal of Vocational Behavior. 68. 446-460. 
TDK, (2019). Sinizm Tanım1. http://www.tdk.gov.tr/index.php?option=com_gts\&arama=gts\&guid=TDK.GTS.580cff050ed 408.78977704 (Erişim: 23.08.2019).

Tokgöz, N. \& Yılmaz, H., (2008). Örgütsel Sinizm: Eskişehir ve Alanya'daki Otel Işletmelerinde Bir Uygulama. Anadolu Üniversitesi Sosyal Bilimler Dergisi. 8(2). 283-305.

Tokgöz, N. (2011). Örgütsel Sinizm, Örgütsel Destek Ve Örgütsel Adalet Ilişkisi: Elektrik Dağıtım Işletmesi Çalışanları Örneği. Eskişehir Osmangazi Üniversitesi İktisadi ve İdari Bilimler Dergisi. 6(2). 363-387.

Yazıcıoglu, Y., ve Erdogan, S. (2004). SPSS Uygulamalı Bilimsel Araştırma Yöntemleri. Ankara: Detay Yayıncılık. 


\title{
Annex: Scales
}

\begin{abstract}
Lütfen aşağıdaki ifadeler arasından, ilk üst'ünüzü (yöneticinizi), çalıştığınız kurumu ve iş arkadaşlarınızı düşünerek (olmasını istediğiniz gibi değil, var olan durumu düşünerek) cevaplandırınız. Size en yakın olan ifadeyi " $X$ " işareti koyarak belirtiniz.

Calıștığım išeri(nde)/kurum(da)/idare(de) ...
\end{abstract}

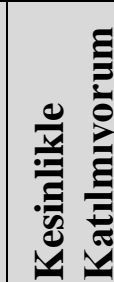

1. ... söylenenler ile yapılanların farklı olduğuna inaniyorum.

2. ... politika, amaç ve uygulamaları arasında çok az ortak yön vardır.

3. ... bir uygulamanın yapılacağı söyleniyorsa, bunun gerçekleşip gerçekleşmeyeceği konusunda kuşku duyarım.

4. ... çalışanlardan bir şey yapmaları beklenir, ancak başka bir davranış ödüllendirilir.

5. ... yapılacağ 1 söylenen şeyler ile gerçekleşenler arasında çok az benzerlik görüyorum.

6. Çalıştı̆̆ım kurumu/işyerini/idareyi düşündükçe sinirlenirim.

7. Çalıştığım kurumu/işyerini/idareyi düşündükçe hiddetlenirim

8. Çalıștığım kurumu/ișyerini/idareyi düşündükçe gerilim yașarım.

9. Çalıştığım kurumu/işyerini/idareyi düşündükçe içimi bir endişe kaplar.

10... dişındaki arkadaşlarıma, işte olup bitenler konusunda yakınırım.

11. Çalıştığım kurumdan ve çalışanlarından bahsedildiğinde, birlikte çalıştığım kişilerle anlamlı bir şekilde bakışırız.

12. Başkalarıyla, çalıştığım kurumdaki işlerin nasıl yürütüldüğü hakkında konuşurum.

13. Başkalarıyla, çalıştığım kurumdaki uygulamaları ve politikaları eleştiririm.

14. ... çalışanlarla ilgili verilecek kararlarda adil davranılır.

15. ... herkes birbirine dürüst davranır

16. ... yaptığım işin karşılığını alıyorum.

17. ... çalışanların performans değerlendirmesi yapılırken adil davranilır.

18. ... kaynaklar dağıtılırken adil davranılır. 


\begin{tabular}{|l|l|l|l|l|l|}
\hline $19 . \ldots$ çalışanların ödüllendirilmesinde adil davranııır & & & & & \\
\hline $\begin{array}{l}20 \ldots \text { çalışanlar ortaya çıkan firsatlardan eşit şekilde } \\
\text { yararlanır. }\end{array}$ & & & & & \\
\hline $21 \ldots$ çalısanlar alınan kararlara katılır. & & & & & \\
\hline $22 . \ldots$ iş yükü çalışanlara eşit olarak dağı̆tılır. & & & & & \\
\hline $23 \ldots$ iş programı yapııırken çalışanlara eşit davranılır. & & & & & \\
\hline
\end{tabular}




\begin{tabular}{|c|c|c|c|c|c|}
\hline $\begin{array}{l}\text { Lütfen aşağıdaki ifadeler arasından, çalıştığınız kurumu, } \\
\text { iş arkadaşlarınızı ve yöneticinizi düşünerek (olmasını } \\
\text { istediğiniz gibi değil, var olan durumu düşünerek) } \\
\text { cevaplandırınız. Size en yakın olan ifadeyi "X" işareti } \\
\text { koyarak belirtiniz. } \\
\text { Calıștığım işyeri(nde)/kurum(da)/idare(de)... }\end{array}$ & 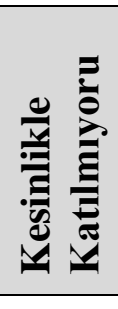 & 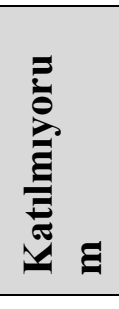 & 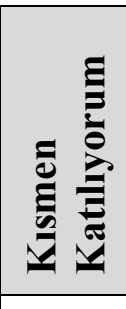 & 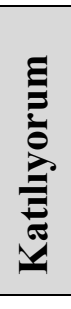 & 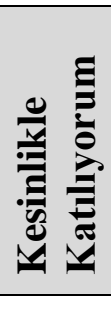 \\
\hline \multicolumn{6}{|l|}{$\begin{array}{l}\text { 24... her çalışanın yapılan uygulamalara itiraz etme } \\
\text { hakkı vardır. }\end{array}$} \\
\hline \multicolumn{6}{|l|}{ 25. ... çalışanlardan gelen itirazlar dikkate alınır. } \\
\hline \multicolumn{6}{|l|}{$\begin{array}{l}\text { 26. ... çalışanlar arasında çıkan çatışmaların çözümünde } \\
\text { tarafsız davranılır. }\end{array}$} \\
\hline \multicolumn{6}{|l|}{ 27. ... çalışanların bireysel farklılıklarına saygı duyulur. } \\
\hline \multicolumn{6}{|l|}{$\begin{array}{l}\text { 28. ... yöneticim hizmet sunduğum kişiler (vatandaş, } \\
\text { öğrenci vb) ile yaşadığım herhangi bir sorunda benim } \\
\text { görüşümü mutlaka alır }\end{array}$} \\
\hline \multicolumn{6}{|l|}{$\begin{array}{l}29 . . . \text { hizmet sunduğum kişilere (vatandaş, öğrenci vb) } \\
\text { karş1 beni korur. }\end{array}$} \\
\hline \multicolumn{6}{|l|}{$\begin{array}{l}30 . . . \text { hizmet sunduğum kişilerle (vatandaş, öğrenci vb) } \\
\text { yaşadığım sorunları çözebilmem için gerekli her türlü } \\
\text { desteği sağlar. }\end{array}$} \\
\hline \multicolumn{6}{|l|}{$\begin{array}{l}31 . . . \text { işimdeki yükselme firsatlarından beni haberdar } \\
\text { eder. }\end{array}$} \\
\hline \multicolumn{6}{|l|}{$\begin{array}{l}\text { 32. ... kendimi mesleki yönden geliştirebilmem (hizmet } \\
\text { içi eğitim, lisansüstü eğitim vb.) için mesai saatlerimde } \\
\text { gerekli düzenlemeleri yapar. }\end{array}$} \\
\hline \multicolumn{6}{|l|}{$\begin{array}{l}\text { 33. ... kazandığı başarılarda çalışanlarının payı olduğunu } \\
\text { düşünür. }\end{array}$} \\
\hline \multicolumn{6}{|l|}{ 34. ... küçük hatalarımı hoş görür. } \\
\hline \multicolumn{6}{|l|}{$\begin{array}{l}35 . . . \text { iş başarılarımdan dolayı yazılı olarak takdir } \\
\text { edilirim. }\end{array}$} \\
\hline \multicolumn{6}{|l|}{$\begin{array}{l}\text { 36.... iş başarılarından dolayı çalışanlara verilen } \\
\text { ödüllerde tutarlı davranılır. }\end{array}$} \\
\hline \multicolumn{6}{|l|}{ 37. ... çalışanlarının iş başarıları ödüllendirilir. } \\
\hline \multicolumn{6}{|l|}{$\begin{array}{l}\text { 38. ... yöneticilerim mümkün olursa ücretimi arttırmayı } \\
\text { düşünür. }\end{array}$} \\
\hline \multicolumn{6}{|l|}{$\begin{array}{l}\text { 39... yöneticilerim mümkün olduğunca işimi ilginç } \\
\text { hale getirmek için uğraşır. }\end{array}$} \\
\hline $\begin{array}{l}40 . . . \text { verilen ödüller ile ilgili olarak çalışanlar } \\
\text { bilgilendirilir. }\end{array}$ & & & & & \\
\hline 41. ... çalışanların iş performansı takdir edilir. & & & & & \\
\hline
\end{tabular}




\begin{tabular}{|c|c|c|c|c|c|}
\hline $\begin{array}{l}\text { Mevcut işinizde aşağıda belirtilen } \\
\text { davranışların her birini ne sıklıkla yaptınız? }\end{array}$ & : & 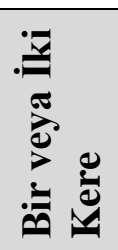 & 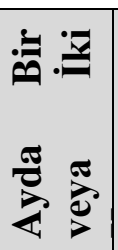 & 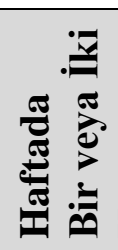 & 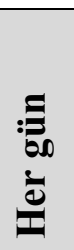 \\
\hline 42. Kasıtlı olarak kurumumuza ait araç ve gereçleri israf ettim. & & & & & \\
\hline $\begin{array}{l}\text { 43. Kasitlı olarak kurumun herhangi bir araç ve gerecine zarar } \\
\text { verdim. }\end{array}$ & & & & & \\
\hline 44. Kasıtlı olarak ofisimi/işyerimi dağınık bıraktım. & & & & & \\
\hline İzinsiz olarak mesaime geç geldim. & & & & & \\
\hline $\begin{array}{l}\text { 46. Hiçbir sağlık sorunum olmadığı halde, hastayım bahanesi } \\
\text { yaparak o gün işe gitmedim. }\end{array}$ & & & & & \\
\hline $\begin{array}{l}\text { 47. İşyerince belirlenen yemek ve dinlenme sürelerini izinsiz } \\
\text { olarak aştım. }\end{array}$ & & & & & \\
\hline 48. İzinsiz olarak mesaimden erken ayrıldım. & & & & & \\
\hline $\begin{array}{l}\text { 49. Gün içerisinde özel işlerimi halletmek için saatlik izin } \\
\text { almadan işyerinden ayrıldım. }\end{array}$ & & & & & \\
\hline $\begin{array}{l}\text { 50. İşten kaytarmak için bir sağlık kuruluşuna giderek, kendimi } \\
\text { gün içerisinde sıhhi izinli gösterdim. }\end{array}$ & & & & & \\
\hline $\begin{array}{l}\text { 51. İşe birkaç gün gitmemek için bir sağlık kuruluşuna giderek } \\
\text { sağlık raporu aldım. }\end{array}$ & & & & & \\
\hline $\begin{array}{l}\text { 52. Tuvalete gitme, sigara içme ve benzeri nedenlerle görevime } \\
\text { (işime) ara verdim ve bu arayı kasten uzattım. }\end{array}$ & & & & & \\
\hline Kasıtlı olarak işimi yanlış yaptım. & & & & & \\
\hline 54. Bitirilmesi gereken acil bir iş varken, bilerek yavaş çalıştım & & & & & \\
\hline $\begin{array}{l}\text { 55. Verilen bir görevi zamanında bitirdiğim halde, yeni bir } \\
\text { görev verilmemesi için görevi henüz tamamlayamadığımı } \\
\text { söyledim. }\end{array}$ & & & & & \\
\hline $\begin{array}{l}\text { 56. Normal koşullarda yapabileceğim bir görevi (işi), ben } \\
\text { üstesinden gelemem diyerek reddettim. }\end{array}$ & & & & & \\
\hline $\begin{array}{l}\text { 57. Normal koşullarda yapabileceğim bir görevi (işi), sağlık } \\
\text { sorunlarım olduğu bahanesiyle reddettim. }\end{array}$ & & & & & \\
\hline 58. Kurumumuzdaki kurallara kasitlı olarak uymadım. & & & & & \\
\hline Kurumumuza ait bir şeyi izinsiz olarak aldım. & & & & & \\
\hline $\begin{array}{l}\text { 60. Kurumumuza ait bazı araç-gereçleri izinsiz olarak evime } \\
\text { götürdüm. }\end{array}$ & & & & & \\
\hline $\begin{array}{l}\text { 61. Normal mesaimden daha fazla çalışmış gibi gösterip, } \\
\text { fazladan ücret aldım. }\end{array}$ & & & & & \\
\hline 62. İzinsiz olarak kurumun parasını aldım / kullandım. & & & & & \\
\hline
\end{tabular}




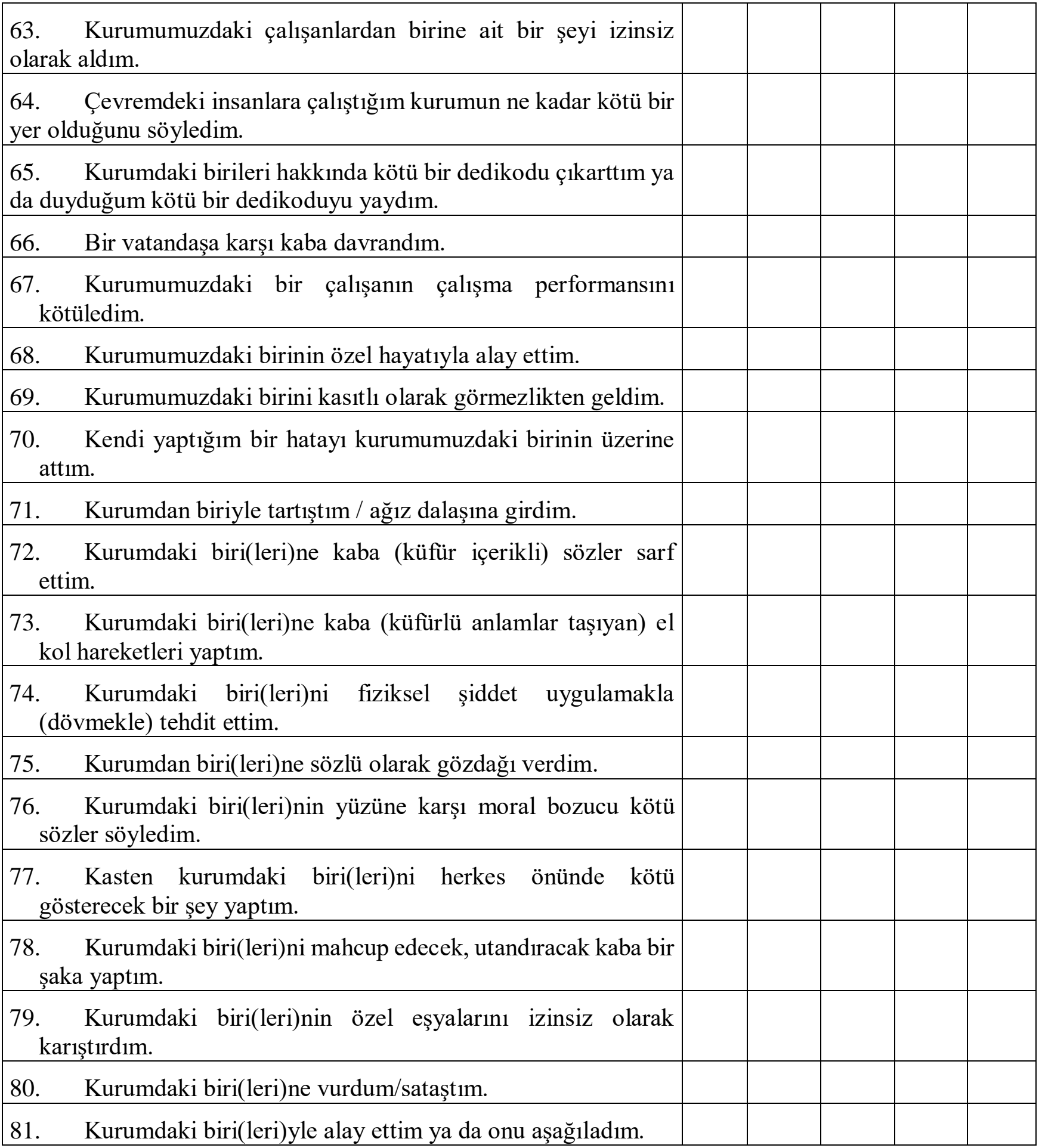

